\author{
ARIANA KORLAET - VESNA MAROHNIĆ-KUZMANOVIĆ - \\ DUBRAVKA ŠEPAROVIĆ
}

\title{
USMJERAVANJE RAZVOJA PODGORJA KROZ PROSTORNO-PLANSKU DOKUMENTACIJU
}

\author{
Ariana Korlaet \\ Vesna Marohnić-Kuzmanović \\ Dubravka Šeparović \\ Hrvatski zavod za prostorni razvoj \\ Ulica Republike Austrije 20 \\ HR 10000 Zagreb \\ ariana.korlaet@mgipu.hr \\ vesna.marohnickuzmanovic@mgipu.hr \\ dubravka.separovic@mgipu.hr
}

UDK: 656.1:711.73(497.5 Podgorje)

Pregledni članak

Ur.: 2017-03-02

U radu se daje pregledni prikaz i analiza razvojnih perspektiva usmjerenja iz prostorno-planske dokumentacije za ostvarivanje razvojnih mogućnosti Podgorja $\mathrm{s}$ obzirom na osobitosti njegova geografskog položaja, reljefno-klimatskih karakteristika i povijesnog naslijeđa, a posebno prednosti i ograničenja za njegov razvoj koja proizlaze iz sustava zaštite cijelog područja. Tematsko područje nalazi se cijelom svojom površinom unutar područja od posebnog interesa za Državu - Zaštićenog obalnog pojasa, unutar Parka prirode Velebit i ekološke mreže RH, odnosno ekološke mreže EU Natura 2000 te u kontaktnom području Nacionalnog parka Sjeverni Velebit i Nacionalnog parka Paklenica.

U važećem sustavu prostornog uređenja razmatrane su postavke strateških dokumenata prostornog razvoja te prostorno-planska dokumentacija za područje Podgorja na tri razine: prostorni planovi državne razine za područja posebnih obilježja, županijski prostorni planovi i prostorni planovi općina i gradova, u okviru teze da je uloga prostornog planiranja integriranje različitih politika koje utječu na određeno područje, pri čemu održivost razvoja proizlazi iz ukupnog sinergijskog razvoja gospodarske, društvene, prirodne/okolišne i kulturne osnove prostora i društva.

Sustav prostornog uređenja primarno je vezan uz teritorijalni ustroj. Zakonom o područjima županija, gradova i općina određene su teritorijalne cjeline koje često ne obuhvaćaju stvarno plansko područje vezano uz pojedine razvojne aspekte i strateška pitanja okoliša. U tom smislu Prostorni plan Parka prirode Velebit će moći sagledati razvojne izazove i potrebe Podgorja kao cjeline.

Ključne riječi: Podgorje, prostorno uređenje, zaštićena područja, prostorni plan, Park prirode Velebit, razvojni ciljevi, razvojni potencijali, razvojna ograničenja 


\section{Uvod}

U radu se daje pregledni prikaz i analiza razvojnih perspektiva usmjerenja iz prostorno-planske dokumentacije za ostvarivanje razvojnih mogućnosti Podgorja ${ }^{1}$, s obzirom na osobitosti njegova geografskog položaja, reljefnoklimatskih karakteristika i povijesnog naslijeđa, a posebno prednosti i ograničenja za njegov razvoj koja proizlaze iz propisanih sustava zaštite. Analiza obuhvaća mogućnosti i ograničenja prostornog razvoja i uređenja s prostorno-planskog aspekta s obzirom na gospodarski razvoj, demografski razvoj, prostornokrajobrazne i prirodne vrijednosti te kulturno-povijesne cjeline i građevine.

Podgorje se razmatra prostorno unutar triju jedinica lokalne samouprave: Grad Senj, Općina Karlobagi Općina Starigrad, kojeunutar svojih administrativnih granica definiraju obuhvat prostornih planova, s posebnim osvrtom na prostor od obalne linije do Jadranske turističke ceste (magistrale), odnosno prve velebitske stepenice (okvirno 300 m n.v.), između naselja Sveti Juraj i Starigrad Paklenica. Tematsko područje nalazi se cijelom svojom površinom u sustavu zaštite po više osnova, stoga je prostorno planiranje posebno razmatrano u korelaciji sa sustavom zaštite prirode i okoliša te obalnog područja.

Prostorno planiranje je proces koji uključuje kontinuiranu provjeru i procjenu mogućnosti korištenja, zaštite i razvoja prostora čiji rezultat su izmjene i dopune postojećih, odnosno izrada i donošenje novih prostornih planova. Time oni postaju važan interdisciplinarni instrument poboljšanja ciljeva i usmjerenja radi kvalitetnijeg razvoja područja. Stoga su razlozi za provođenje istraživanja vezani uz potrebu sveobuhvatnog sagledavanja razvojnih teškoća Podgorja, pogođenog negativnim demografskim trendovima, koje bi moglo dati doprinos u okviru predstojeće izrade Prostornog plana PP Velebit.

U važećem sustavu prostornog uređenja razmatrane su postavke strateških dokumenata prostornog razvoja te prostorno-planska dokumentacija za područje Podgorja na tri razine: prostorni planovi državne razine za područja posebnih obilježja, županijski prostorni planovi i prostorni planovi općina i gradova, $u$ okviru teze da je uloga prostornog planiranja integriranje različitih politika koje utječu na određeno područje, pri čemu održivost razvoja proizlazi iz ukupnog sinergijskog razvoja gospodarske, društvene, prirodne/okolišne i kulturne osnove prostora i društva.

${ }^{1}$ Velebitsko podgorje, područje u podnožju Velebita, između Senja i rijeke Zrmanje (mrežno izdanje Hrvatske enciklopedije Leksikografskog zavoda Miroslav Krleža, http://www. enciklopedija.hr/Natuknica.aspx?ID=64114) 
Prostorno planiranje ima odgovornost za prostornu koheziju u smislu osiguravanja podjednakih životnih uvjeta na svim područjima uz prepoznavanje lokalnih potencijala razvoja u skladu s gospodarskim, društvenim i kulturnim ciljevima usuglašenima na svim razinama.

Promišljanje prostornog razvoja i planiranja nadilazi granice teritorijalne podjele, iako sustav prostornog uređenja upućuje na dominantnu vezanost prostornog planiranja uz teritorijalni ustroj, dok prostorni obuhvat prostornih planova područja posebnih obilježja određuje prepoznate izuzetne prirodne vrijednosti i/ili osobitosti.

U radu se primjenom analitičkih metoda istražuje suvremena zakonska osnova planiranja prostora Podgorja i važeći prostorni planovi, uz usporednu analizu razvojnih ograničenja i potencijala koji proizlaze iz drugih sektorskih politika zaštita prirodnih i okolišnih vrijednosti, regionalni razvoj, ruralni razvoj i turizam. Sintezom podataka različitih vrsta i razina planskih dokumenata dat će se usmjerenja za budući planerski odnos prema prirodnoj i kulturnoj baštini, tradicionalnoj gradnji i gospodarskom razvoju te postojećim naseljima u smislu njihove revitalizacije, međusobnog povezivanja i mogućem pozicioniranju u mreži naselja.

\section{Prostorno planiranje i uređenje}

Prostorno planiranje je geografski izraz ekonomske, socijalne, kulturne $i$ ekološke politike društva. Ono je istovremeno znanstvena disciplina, administrativna tehnika i politika zamišljena kao interdisciplinarni $i$ globalni pristup usmjeren uravnoteženom regionalnom razvoju $i$ fizičkoj organizaciji prostora prema cjelovitoj strategiji. ${ }^{2}$

Sustav prostornog uređenja u Republici Hrvatskoj uređen je zakonom ${ }^{3}$ i propisima donesenim na temelju tog zakona. Njima se između ostalog, uz poštivanje općih ciljeva i primjenom načela prostornog uređenja, uređuju uvjeti planiranja prostora, postupak izrade i donošenja prostornih planova te njihov obvezni sadržaj, razine donošenja i provedba.

Prostornim uređenjem osiguravaju se uvjeti za gospodarenje prostorom, kao osobito vrijednim i ograničenim nacionalnim dobrom, koje uključuje stvaranje pretpostavki za društveni i gospodarski razvoj, zaštitu okoliša i prirode, vrsnoću gradnje i racionalno korištenje prirodnih i kulturnih dobara te upravljanje prostorom.

${ }^{2}$ Europska povelja o regionalnom/prostornom planiranju (često nazivanoj Torremolinoska povelja) koju je 1983. prihvatila Europska konferencija ministara nadležnih za prostorno planiranje (CEMAT).

${ }^{3}$ Zakon o prostornom uređenju. //Narodne novine, br. 153/13. 
Prostorni planovi imaju snagu podzakonskih propisa, a ovisno o njihovoj razini, uz poštivanje načela vertikalne integracije donose ih odgovarajuća predstavnička tijela, Državaijedinice lokalne i područne(regionalne) samouprave, te druga javnopravna tijela koja pritom međusobno surađuju i uvažavaju ciljeve $\mathrm{i}$ interese izražene u prostornim planovima više razine, odnosno šireg područja. Razine prostornih planova jesu:

- LOKALNA - prostorni plan uređenja grada/općine (PPUG/O), generalni urbanistički plan (GUP) i urbanistički plan uređenja (UPU)

- PODRUČNA (REGIONALNA) - prostorni plan županije (PPŽ)/Prostorni plan Grada Zagreba (PPGZ), Urbanistički plan uređenja županijskog značaja

- DRŽAVNA - Državni plan prostornog razvoja (DPPR), prostorni planovi područja posebnih obilježja (PPPPO) i Urbanistički plan uređenja državnog značaja.

Prostorni planovi uređenja gradova/općina određuju građevinska područja pripadajućih naselja, obuhvate planova užeg područja unutar obuhvata (UPU, GUP) i koridore infrastrukture od značaja za područje te propisuju uvjete provedbe svih zahvata u prostoru za koje se ne donosi plan užeg područja, osim zahvata državnog i županijskog značaja.

Županijski planovi između ostalog propisuju uvjete provedbe zahvata u prostoru za javne, društvene i druge građevine područnog (regionalnog) značaja te uvjete provedbe zahvata u prostoru područnog (regionalnog) značaja.

Prostorni planovi državne razine određuju površine državnog značaja i uvjete provedbe zahvata u prostoru koji se na njima planiraju. Prostorni planovi posebnih obilježja izrađuju se i donose ovisno o posebnostima prirodnih, kulturno povijesnih, gospodarskih i/ili drugih obilježja, odnosno zahtjeva određenog prostora. S obzirom na ostale prostorne planove u sustavu prostornog uređenja složeniji su u postupku izrade i donošenja.-

U izradu prostornog plana državne razine, uključena je i Vlada Republike Hrvatske donošenjem odluke o njegovoj izradi, utvrđivanjem prijedloga plana za javnu raspravu i konačnog prijedloga plana te njegova upućivanja Hrvatskom saboru na donošenje, što u konačnici rezultira dugotrajnijim postupkom izrade i donošenja, odnosno izmjene i dopune plana. Zbog složenosti postupka izrade i donošenja ovih planova koordinaciju izrade i praćenje provedbe prostornih planova državne razine provodi Hrvatski zavod za prostorni razvoj.

Postupak izrade prostornih planova prate postupci strateške procjene utjecaja na okoliš (SPUO) i glavne ocjene utjecaja na ekološku mrežu (GO). Ovi 
postupci započinju u najranijoj fazi izrade planova i predstavljaju dodatni kontrolni mehanizam kojim se, u okviru općih smjernica propisanih posebnim zakonima ${ }^{4} \mathrm{i}$ propisima, valoriziraju pojedina planska rješenja za uređenje i korištenje prostora te preciznije određuju mjere zaštite pojedinih sastavnica okoliša (zrak, vode, more, tlo, biljni i životinjski svijet, zemljina kora) i zaštićenih dijelova prirode.

\section{Podgorje u sustavu prostornih planova}

Područje Podgorja, premda u geografskom smislu nije veliko, obuhvaćeno je prostornim planovima svih triju razina. Danas su na tom uskom ali dugačkom dužobalnom podvelebitskom području na snazi:

- na lokalnoj razini prostorni planovi grada i općina: Prostorni plan uređenja Grada Senja ${ }^{5}$ Prostorni plan uređenja Općine Karlobag ${ }^{6}$, Prostorni plan uređenja Općine Starigrad ${ }^{7}$, koji su odredili razvoj naselja i građevinskog područja te planovi užih područja unutar njihovih obuhvata

- na područnoj razini prostorni planovi županija: Prostorni plan Ličkosenjske županije ${ }^{8}$ i Prostorni plan Zadarske županije ${ }^{9}$, koji su odredili smjernice i prepoznali ciljeve za razvojne potrebe područja županije

- na državnoj razini prostorni planovi posebnih obilježja u kontaktnom području Podgorja: Prostorni plan Nacionalnog parka Sjeverni Velebit ${ }^{10}$ i Prostorni plan Nacionalnog parka Paklenica ${ }^{11}$, koji osiguravaju zaštitu prirodnih, okolišnih, kulturnih i drugih vrijednosti područja te određuju uvjete i mogućnost održivog razvoja kompatibilnih djelatnosti uz unapređivanje primarne ekološke, znanstveno-edukativne i izletničkorekreacijske funkcije tih parkova.

${ }^{4}$ Zakon o zaštiti okoliša. // Narodne novine, br. 80/13, 153/13 i 78/15, Zakon o zaštiti prirode. //Narodne novine, 153/13.

${ }^{5}$ Prostorni plan uređenja Grada Senja. // Službeni glasnik Grada Senja, br. 11/06, 1/12, 6/14 i $10 / 14$.

${ }^{6}$ Prostorni plan uređenja Općine Karlobag. // Županijski glasnik Ličko-senjske županije, br.3/08 i $12 / 10$.

${ }^{7}$ Prostorni plan uređenja Općine Starigrad. // Službeni Glasnik Zadarske županije, br.16/06, $14 / 11$ i $20 / 16$.

${ }^{8}$ Prostorni plan Ličko-senjske županije. // Županijski glasnik ličko-senjske županije, br. 16/02, 17/02, 19/02, 24/02, 3/05, 3/06, 15/06, 19/07, 13/10, 22/10, 19/11, 4/15, 7/15 i 6/16.

${ }_{9}$ Prostorni plan Zadarske županije. // Službeni Glasnik Zadarske županije, br. 2/01, 6/04, 2/05, 17/06, 25/09, 3/10, 15/14, 14/15 i 20/16.

${ }^{10}$ Prostorni plan Nacionalnog parka Sjeverni Velebit. // Narodne novine, br. 35/12.

${ }^{11}$ Prostorni plan Nacionalnog parka Paklenica. // Narodne novine, br. 23/01. 
Cijelo područje Podgorja nalazi se unutar obuhvata Parka prirode Velebit za koji će se izraditi prostorni plan državne razine - Prostorni plan Parka prirode Velebit. Tim planom će se, u okviru postavljene optimalne zaštite prostora, propisati mjere za unapređenje i zaštitu prirode, okoliša, kulturnih dobara i drugih vrijednosti područja te uvjeti provedbe planiranih zahvata u prostoru.

\section{Prostorni plan Parka prirode Velebit}

Planinski masiv Velebita proglašen je parkom prirode 1981. godine. $\mathrm{S}$ površinom od $2.000 \mathrm{~km}^{2}$ čini gotovo polovicu površine ukupno zaštićenih područja prirode u Republici Hrvatskoj, stoga svojom veličinom i položajem te klimatskom i reljefnom raznolikošću predstavlja vrlo zahtjevno područje za izradu jedinstvenog prostornog plana državne razine.

Prioritetni cilj planiranja u zaštićenim područjima prirode, u kojima u pravilu prevladava i značajnija je restriktivna komponenta od razvojne, svakako je očuvanje prirodnih, kulturno-povijesnih, ekoloških i krajobraznih vrijednosti zbog kojih je područje i proglašeno zaštićenim. Načelo prostorne održivosti razvoja, jedno od temeljnih načela prostornog uređenja, ovdje postaje prioritetno načelo.

Prostorni plan Parka prirode Velebit još nije donesen, ali je započeta izrada stručno - analitičkih poslova u sklopu pripremnih radova koji obuhvaćaju, između ostalog, detaljne analize prostorno relevantnih podataka - važeće prostorno planske dokumentacije i postojećeg stanja, građevinskih područja, zgrada i građevina izvan građevinskih područja, postojeće infrastrukture, postojeće zonacije i namjene površina, sustava i tipologije naselja, demografskih kretanja i djelatnosti, uključujući dostupnu stručnu literaturu te izradu fotodokumentacije i provođenje anketa i sastanaka s lokalnim stanovništvom i drugim dionicima.

Razvojna komponenta Velebita treba se oslanjati na njegove komparativne vrijednosti i prednosti te često kontrastne potencijale kao što su prirodni fenomeni, kulturno-povijesne i tradicijske vrijednosti, odnos more-obalni pojasplanina, te na usklađivanje i usmjeravanje različitih interesa u prostoru, kao što su poljoprivreda, šumarstvo, diversifikacija turizma (izletnički, planinarski, speleološki, lovni...), energetika, promet, naselja i dr. Pri tom je sve prirodne i obnovljive gospodarske resurse Parka prirode Velebit potrebno maksimalno zaštititi od nenamjenske uporabe, ekološki dvojbene industrije i drugih neprimjernih gospodarskih ili graditeljskih aktivnosti uz prilagođavanje svih zahvata u prostoru, a posebno arhitekture tradicijskim značajkama te afirmiranje tradicijskih vrijednosti. 


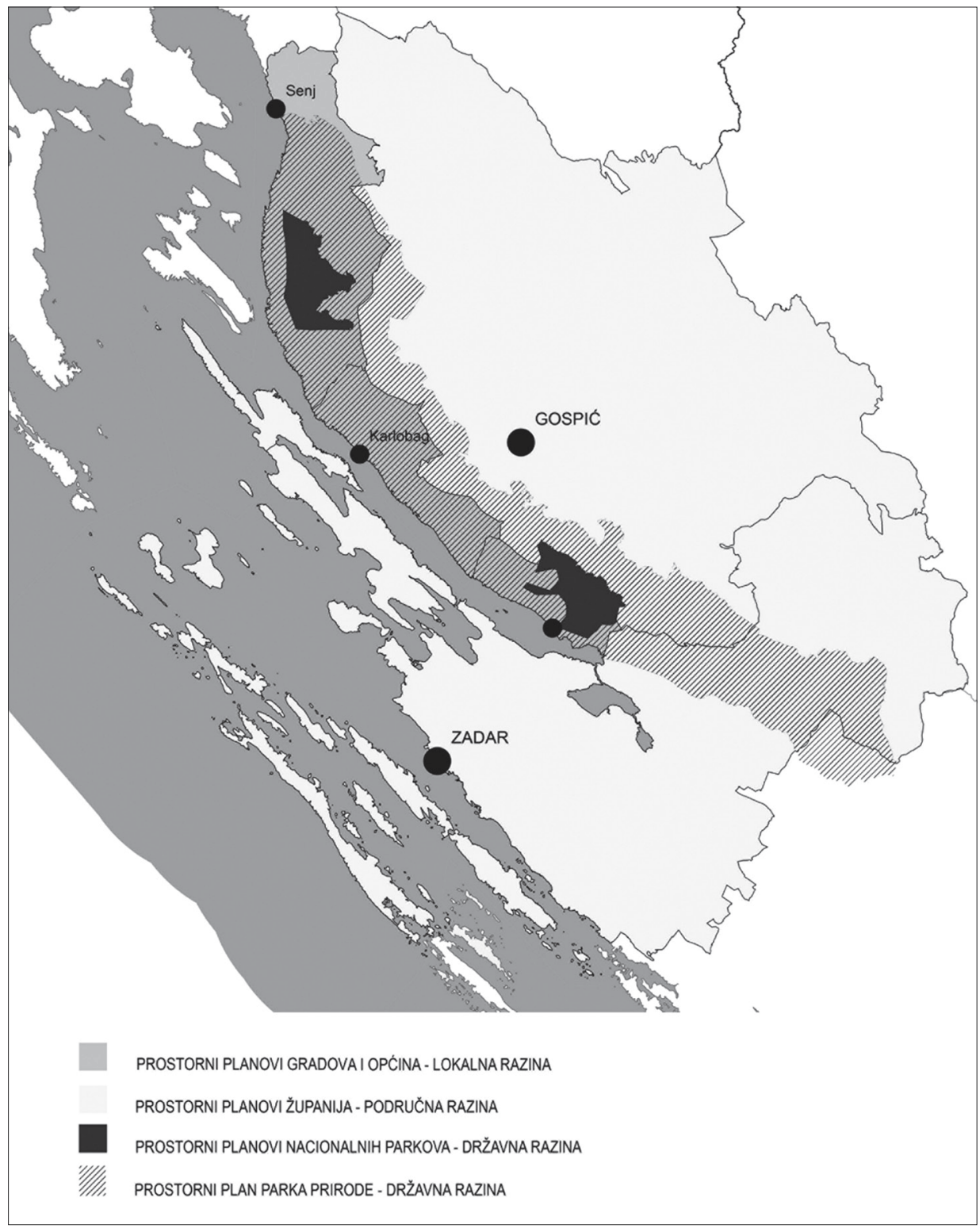

Prikaz 1. Prostorni planovi u Podgorju, izvor: Državna geodetska uprava 2014. godina, Državni zavod za zaštitu prirode 2014. godina, grafička obrada: Sunčana Vrbat, Hrvatski zavod za prostorni razvoj 
Za formiranje kvalitetnog odnosa prema prirodnim vrijednostima i kulturnopovijesnom nasljeđu Podgorja nužna je valorizacija prirodne i kulturne baštine, tradicionalnih oblika građenja te krajobraznih vrijednosti kao podloga za plansko odlučivanje o tome koje dijelove treba očuvati u izvornom obliku, a koji se mogu koristiti, uz određene uvjete održivosti te vrsnoće oblikovanja i gradnje, na način koji ovom kraju omogućava uvjete za opstojnost (lokalnom stanovništvu i parku prirode kao cjelini). O tome ovisi i efikasnost sustava upravljanja graditeljskom baštinom, kao i njezina uporabna vrijednost te uspostava odnosa između izvorne graditeljske baštine i suvremenih graditeljskih trendova, posebno na područjima povijesnih ruralnih cjelina i urbanih obalnih jezgri.

\section{Podgorje u sustavu zaštite}

Područje Podgorja nalazi se cijelom svojom površinom unutar područja od posebnog interesa za Državu - Zaštićenog obalnog područja mora, Parka prirode Velebit i ekološke mreže RH, odnosno ekološke mreže EU Natura 2000, te u kontaktnom području Nacionalnog parka Sjeverni Velebit i Nacionalnog parka Paklenica.

Prostor Podgorja zaštićen je po dvije osnove: Zakonom o zaštiti prirode štite se prirodne vrijednosti, a Zakonom o prostornom uređenju posebno se štiti obalno područje mora.

Prema Zakonu o zaštiti prirode organizacija prostora, način korištenja, uređenja i zaštite prostora u nacionalnom parku i parku prirode koje Hrvatski sabor proglašava zakonom, uređuju se prostornim planom područja posebnih obilježja, na temelju stručne podloge zaštite prirode koju izrađuje Državni zavod za zaštitu prirode (danas u sklopu Hrvatske agencije za okoliš i prirodu).

Podgorje se u cijelosti nalazi unutar granica Parka prirode Velebit i u kontaktnom području Nacionalnog parka Sjeverni Velebit i Nacionalnog parka Paklenica za koje su doneseni prostorni planovi te je neupitan i značajan međuutjecaj tih zaštićenih područja na razvoj Podgorja.

U naseljenim dijelovima zaštićenih područja kao što je Podgorje, u kojemu se naselja nalaze unutar parka prirode, teži se iznalaženju optimalnog odnosa između održivosti i suživota čovjeka i prirode, kako bi se u najvećoj mogućoj mjeri očuvale prirodne vrijednosti, iskoristile komparativne prednosti zaštite i prirodni potencijali prostora te vodeći računa o osjetljivosti i dopustljivom opterećenju prostora, omogućio razvoj uz unapređivanje primarne ekološke, znanstveno-edukativne i izletničko-rekreacijske funkcije Parka. 


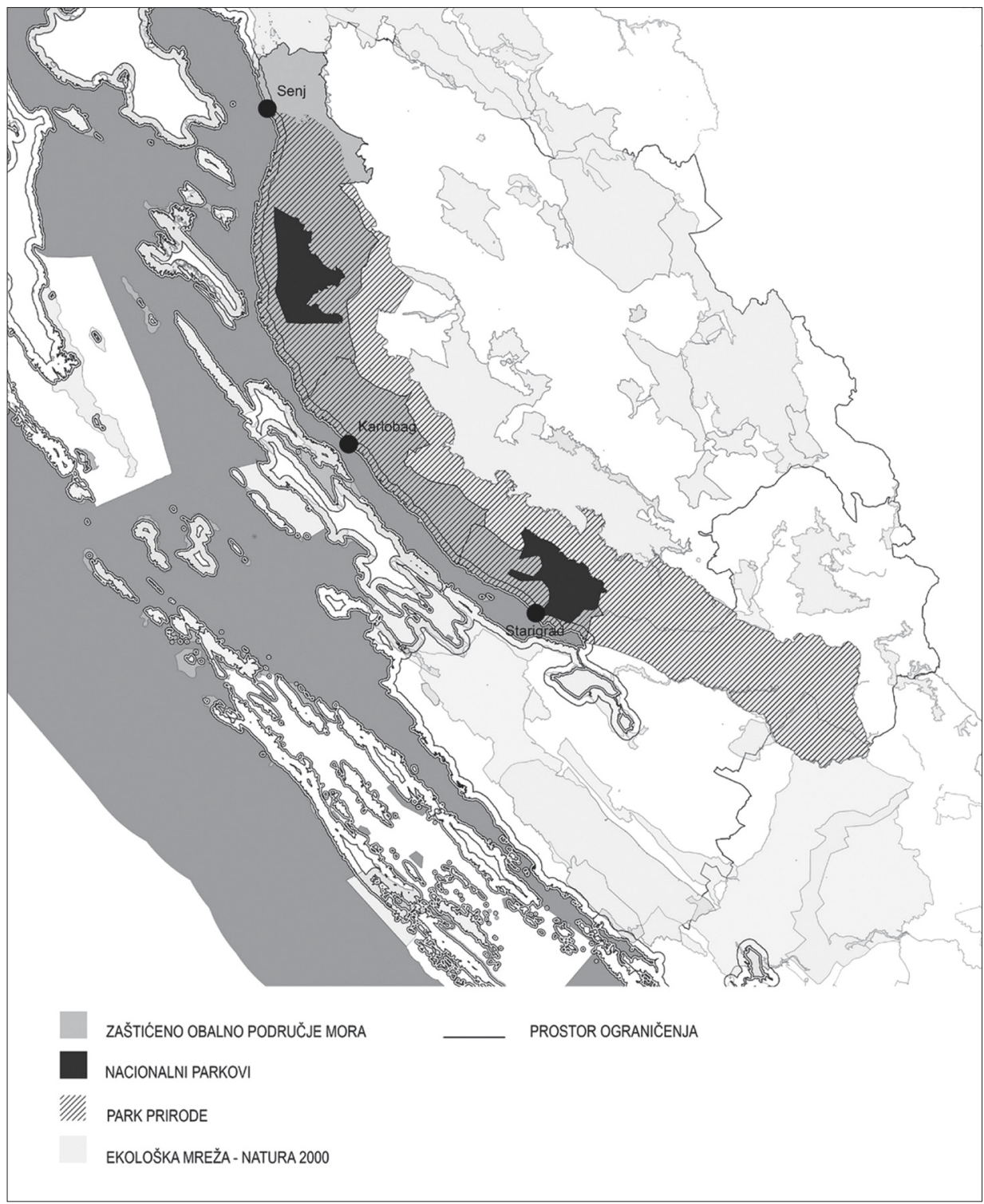

Prikaz 2. Zaštićena područja Podgorja, izvor: Državna geodetska uprava 2014. godina, Državni zavod za zaštitu prirode 2014. godina, grafička obrada: Sunčana Vrbat, Hrvatski zavod za prostorni razvoj 
Zaštićenim područjima prirode upravljaju javne ustanove koje osniva Republika Hrvatske, a kojima je dodijeljena djelatnost zaštite, održavanja, promicanja i nadziranja zaštićenog područja u cilju zaštite i očuvanja izvornosti prirode, osiguravanja neometanog odvijanja prirodnih procesa i održivog korištenja prirodnih dobara.

Zakonom o prostornom uređenju određeno je zaštićeno obalno područje mora (ZOP) kao područje od posebnog interesa za Republiku Hrvatsku, a obuhvaća obalne jedinice lokalne samouprave. S namjerom dodatne zaštite te ostvarenja ciljeva održivog, svrhovitog i gospodarski učinkovitog razvoja Republike Hrvatske, određen je pojas kopna i otoka u širini od $1000 \mathrm{~m}$ od obalne crte i pojas mora u širini od $300 \mathrm{~m}$ od obalne crte (prostor ograničenja) u kojem se planiranje i korištenje prostora ZOP-a može odvijati uz posebna ograničenja.

Svi prostorni planovi u području ograničenja moraju poštivati zakonom određene smjernice prostornog planiranja u ZOP-u, između ostalog: očuvanje i sanacija ugroženih područja prirodnih, kulturno-povijesnih i tradicijskih vrijednosti obalnog i zaobalnog krajolika te poticanje prirodne obnove šuma i autohtone vegetacije, osiguravanje slobodnog pristupa obali, prolaz uz obalu te javni interes u korištenju pomorskog dobra, uvjetovanje razvoja infrastrukture zaštitom i očuvanjem vrijednosti krajolika, ograničavanje međusobnog povezivanja i dužobalnog proširenja postojećih građevinskih područja, odnosno nova građevinska područja planirati izvan površina koje su u naravi šume.

Dodatno je još zaštićen prostor ograničenja sužavanjem dijapazona djelatnosti koje se mogu planirati unutar njega, pa je tako zabranjeno: istraživanje i eksploatacija mineralnih sirovina, iskorištavanje snage vjetra, obrada otpada, uzgoj plave ribe, planiranje privezišta i luka nautičkog turizma te nasipavanje obale izvan građevinskog područja i slično. Navedena ograničenja ne odnose se na djelatnosti i građevine koje po svojoj prirodi zahtijevaju smještaj na obali te uređenje javnih površina.

U ZOP-u i u prostoru ograničenja propisana su i ograničenja za određivanje novih građevinskih područja i mogućnost povećanja postojećih.

Primarni sukob interesa između pojedinih kategorija korisnika i sustava zaštite prostora u procesu planiranja događa se na razini neposrednih korisnika prostora i uvjeta njegove zaštite. Stalno stanovništvo najčešće se osjeća zakinutim u pravima korištenja i raspolaganja vlasništvom u zaštićenim prostorima, a lokalna zajednica sputanom u svojim razvojnim vizijama i željama koje bi mogla ostvariti aktiviranjem potencijala prostora izvan sustava zaštite. S druge strane, 
pojedine kategorije korisnika - jedinice lokalne samouprave, županije, država i Javne ustanove na upravljačkoj razini te lokalno stanovništvo i povremeni korisnici - imaju različite, često međusobno suprotstavljene, aspiracije na prostor. Sustav prostornog planiranja i uređenja, koji je temeljno integrativan, doživljava se pritom kao dodatna represija, a ne kao instrument za usuglašavanje/ balansiranje velikog broja interesa u iznalaženju optimalnih razvojnih rješenja.

\section{Naselja u Podgorju}

Prostorna struktura naselja u Podgorju rezultat je sinergijskih utjecaja reljefnih i klimatskih danosti, povijesnog nasljeđa i primarnih oblika privređivanja stanovništva. $\mathrm{S}$ tim u vezi uočljiv je polaritet između naselja na obali i u zaleđu. Obalna naselja tipično su mediteranska, većinom s urbanim identitetom, dok su kontinentalna naselja manja s ruralnim obilježjima i sastavljena od brojnih raspršenih zaselaka sa svega desetak stanovnika.

Točke naseljavanja vezane su uz:

- zelene/plodne oaze u kršu

- zaravni u strmom i krševitom reljefu, zaštićene od bure i pogodne za ispašu

- aktivne prometne smjerove

- na obali uvale pogodne za smještaj luka

- kopnene prometnice - povijesno uzduž i na čvorištima poprečnih veza unutrašnjosti s morem, danas uz Jadransku magistralu.

Osnovu prostornog i gospodarskog razvoja zaleđa Podgorja kroz dugi niz godina činilo je iskorištavanje drva velebitskih šuma i dvojna zemljoradničkostočarska gospodarstva $\mathrm{s}$ ljetnim izmještanjem prema višim planinskim pašnjacima. Tipologija izgrađenih struktura na ovom području vezana je uz sezonsko kretanje stanovnika na tri visinska pojasa odnosno velebitske stepenice (terase).

Oblik egzistencijalnih gospodarskih aktivnosti nije se mijenjao sve do sredine dvadesetog stoljeća kada se, zbog razvoja turizma, značajno promijenila gospodarska struktura u cijelom priobalju. Preseljenjem iz brdskih u razvojno perspektivnije priobalne dijelove postupno je odumiralo stočarstvo i ratarstvo, a time i podgorska naselja u zaleđu.

U tradicionalnoj gradnji na prostoru Podgorja (pastirski stanovi, suhozidi, podzidi, vodoopskrbni objekti - snježnice, bunari, šterne i dr.) pokazuje se graditeljsko umijeće narodnih graditelja i inherentan smisao za 
Tablica 1. Kretanje broja stanovnika i broja kućanstava od 1991. do 2011. u naseljima Podgorja u gradu Senju i općini Karlobag

\begin{tabular}{|c|c|c|c|c|c|c|c|}
\hline \multirow{2}{*}{$\begin{array}{l}\text { Grad/ } \\
\text { Općina }\end{array}$} & \multirow[t]{2}{*}{ Naselje } & \multicolumn{3}{|c|}{ Broj stanovnika } & \multicolumn{3}{|c|}{ Broj kućanstava } \\
\hline & & 1991. & 2001. & 2011. & 1991. & 2001. & 2011. \\
\hline \multirow{7}{*}{ 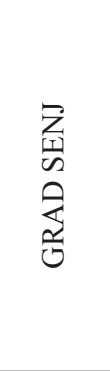 } & Jablanac & 158 & 118 & 83 & 65 & 60 & 47 \\
\hline & Klada & 49 & 33 & 39 & 20 & 16 & 21 \\
\hline & Lukovo & 57 & 36 & 36 & 36 & 21 & 26 \\
\hline & Prizna & 79 & 56 & 45 & 39 & 31 & 26 \\
\hline & Starigrad Senj & 29 & 11 & 15 & 13 & 9 & 11 \\
\hline & Stinica & 145 & 105 & 73 & 60 & 48 & 36 \\
\hline & Sveti Juraj & 691 & 692 & 599 & 236 & 235 & 238 \\
\hline \multirow{8}{*}{ 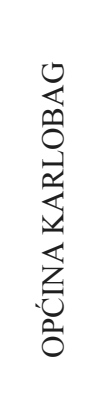 } & Barić Draga & 85 & 124 & 125 & 36 & 54 & 62 \\
\hline & Cesarica & 115 & 144 & 123 & 51 & 76 & 79 \\
\hline & Karlobag & 467 & 510 & 468 & 168 & 216 & 207 \\
\hline & Konjsko & 10 & 7 & 0 & 4 & 4 & 0 \\
\hline & Lukovo Šugarje & 136 & 79 & 68 & 54 & 38 & 39 \\
\hline & Staništa & 48 & 10 & 6 & 14 & 4 & 3 \\
\hline & Sušanj Cesarički & 28 & 13 & 12 & 9 & 6 & 6 \\
\hline & Vidovac Cesarički & 32 & 63 & 56 & 10 & 25 & 26 \\
\hline
\end{tabular}

Izvor: Državni zavod za statistiku, 1991., 2001. i 2011. godina, obrada podataka: Rafaela Kovačević-Pašalić, Hrvatski zavod za prostorni razvoj

oblikovanje, savršeno uklapanje u prirodno okružje, prilagodbu prirodnim fenomenima (zaklon od bure i nanosa snijega, izloženost suncu) i dobra procjena pregleda nad okolicom. Nestankom tradicionalnoga pastirskog života nestala je izvorna funkcija tih građevina i prostora te se otvaraju pitanja oblika njihove revitalizacije odnosno stavljanja u uporabu.

Dok su poljoprivredne aktivnosti bile konstanta kroz dugi niz godina, aktivnost korištenja, odnosno gašenje pojedinih prometnih pravaca značajno je utjecalo na oscilacije i dinamiku razvoja naselja uz njih. Razvoj turizma i smještaj uz glavni dužobalni cestovni pravac omogućili su opstanak obalnih čvorišta na izlazu napuštenih povijesnih kopnenih transverzala preko Velebita (trase Jozefinske i Karolinske ceste).

Nedostatna opremljenost cjelokupnom infrastrukturom naselja (prometnom, energetskom, komunalnom i društvenom) na cijelom području 
posljedica je dugogodišnjih zastoja u razvoju, raspršenosti malog broja stanovnika na velikoj površini te reljefnih i klimatskih danosti. Povećano zauzimanje prostora u obalnom dijelu Podgorja, pretežito za povremeno korištenje u turističke svrhe također nije pratila izgradnja potrebne infrastrukture.

Odrednica koja bitno i dugoročno utječe na mogućnosti prostornog razvoja je stanovništvo. Dugotrajno iseljavanje, pretežito mladog stanovništva, u urbana područja izvan Podgorja uz negativno prirodno kretanje stanovništva (pad nataliteta i starenje) postupno su u fizičkom smislu doveli do smanjenja gustoće naseljenosti, slabljenja lokalnih središnjih naselja i demografskog odumiranja pojedinih naselja, čime je umanjena osnova za razvijanje potencijala.

Pored trajnog iseljavanja, jedna od konstanta na ovom prostoru, koja utječe na fizionomiju i pravce razvoja naselja je sezonalnost kretanja stanovnika. Ranije je smjer kretanja bio uvjetovan međuodnosom djelatnosti i klime i odvijao se unutar područja Podgorja (u smjeru obala-zaleđe ili u zaleđu niži-viši predjeli), a danas se ogleda u formi povremenog stanovanja vezanog uz turizam, s bitno drugačijim motivima, radijusom i pravcima kretanja. Intenzitet i različite opcije korištenja građevina za povremeno stanovanje predstavljaju dodatni pritisak na planiranje kapaciteta i funkcioniranje cjelokupne infrastrukture $u$ naseljima stalnog karaktera.

Prostornim planovima predviđena je mogućnost povećanja postojećih građevinskih područja koje ne prati stvarno demografsko stanje. Prognoze rasta baziraju se na planiranom gospodarskom razvoju koji bi zadržao sadašnje i privukao novo stanovništvo.

\section{Podgorje u sustavu naselja Republike Hrvatske}

Razvojni potencijal prostora temelji se na sustavu naselja. Strateški dokumenti prostornog uređenja Republike Hrvatske ${ }^{12}$ usmjeravaju razvoj sustava naselja prema uspostavljanju hijerarhijski uslojene policentrične mreže kao prostornog okvira za teritorijalno uravnotežen razvoj gospodarstva, infrastrukture i gustoće naseljenosti. U restrukturiranju i popunjavanju postojeće mreže naglašen je značaj jačanja uloge srednje velikih i malih gradova, pogotovo u područjima posebnih obilježja i razvojno specifičnim područjima. Potonje uključuje ruralna te brdsko-planinska područja koja čine površinski najveći dio Podgorja.

${ }^{12}$ Strategija prostornog uređenja Republike Hrvatske (1997), Program prostornog uređenja Republike Hrvatske (1999), Konačni prijedlog Strategije prostornog razvoja Republike Hrvatske (2017). 
Za optimalan razvoj sustava naselja nužna je dostupnost infrastrukture - društvene, prometne i komunalne. U području Podgorja vidljiva je praznina u mreži naselja na državnoj i regionalnoj razini. Senj (4.810 stanovnika), kao subregionalno gravitacijsko središte šireg područja, nalazi se na sjevernom rubu područja i prostorno se ne doživljava kao dio Podgorja, a regionalno središte Gospić fizički je odvojeno Velebitom i prometno teško dostupno. Jedan od temeljnih izazova je optimiziranje lokalne mreže naselja na ovom području poticanjem razvoja lokalnih središta i prenošenjem dijela središnjih funkcija na pojedina naselja.

\section{Sustav naselja u Podgorju}

Veći dio Podgorja ima sva obilježja ruralnog područja Hrvatske: negativne demografske, gospodarske i razvojne trendove te prostornu strukturu koju obilježava velika raspršenost i nedovoljno razvijena mreža središnjih naselja. Ovo rijetko naseljeno područje udaljeno je od razvijenih razvojnih žarišta (Rijeka i Zadar), a okolna središnja naselja nedovoljno su funkcionalno i demografski razvijena da bi preuzela ulogu pokretača razvoja. Nedostatni kapaciteti za stvaranje održivih radnih mjesta uzrok su sporijeg rasta i zaostajanja u razvoju naselja, što posljedično vodi prema trajnom iseljavanju i gubitku stanovništva, dok prostorna usitnjenost umanjuje mogućnost infrastrukturnog povezivanja i umrežavanja.

Raspodjela središnjih funkcija u sustavu naselja temelji se na teritorijalnom ustroju, koji je primarno rezultat političkog, a ne prostornog promišljanja. Razvoj naselja na lokalnoj razini prati gospodarsku konjunkturu, a manje je rezultat građenja zacrtane prostorne strukture.

Jedna od tema prostornih planova je određivanje sustava naselja u funkciji ravnomjernog prostornog razvoja određenog područja, pri čemu se prepoznaju naselja koja mogu biti podrška i pokretači tog razvoja. Kao obalna lokalna razvojna središta s urbanim identitetom za područje Podgorja prepoznati su Karlobag (468 stanovnika) i Starigrad (1.140 stanovnika), a naselja Sveti Juraj, Jablanac, Cesarica, Lukovo Šugarje i Barić Draga kao manja lokalna središta. $\mathrm{S}$ obzirom na prostorni raspored izgrađenih struktura, jačanje mreže naselja u obalnom dijelu predviđeno je raspodjelom središnjih funkcija između susjednih naselja na relaciji Senj-Sveti Juraj, Jablanac-Stinica i Karlobag-Staništa. Za naselja s prevladavajućim ili izrazitim ruralnim obilježjima, koja imaju vitalnu gospodarsku osnovu ili povoljan smještaj u težištu prostornih mikrocjelina, treba osmisliti model jačanja potencijala za preuzimanje pokretačke razvojne 


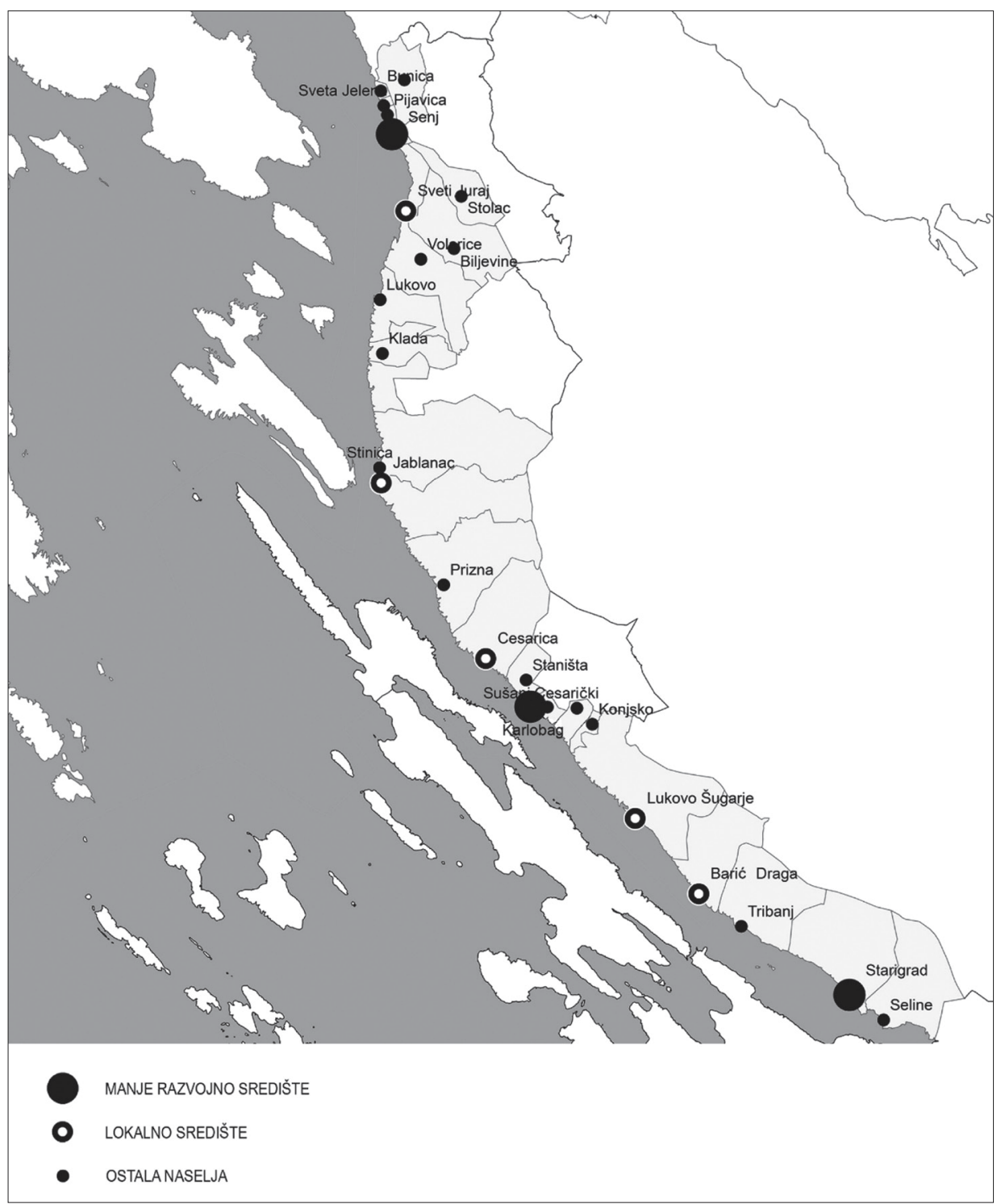

Prikaz 3. Sustav naselja Podgorja, izvor: Državna geodetska uprava 2014. godina, Prostorni plan uređenja Grada Senja (Službeni glasnik Grada Senja br. 11/06, 1/12, 6/14 i 10/14), Prostorni plan uređenja Općine Karlobag (Županijski glasnik Ličko-senjske županije br.3/08 i 12/10), Prostorni plan uređenja Općine Starigrad (Službeni Glasnik Zadarske županije br.16/06, 14/11 i 20/16), grafička obrada: Sunčana Vrbat, Hrvatski zavod za prostorni razvoj 
uloge. Grad Senj je u svom prostornom planu prema tim kriterijima prepoznao u velebitskom zaleđu Krasno kao potencijalno lokalno razvojno središte te uključivanje naselja Krivi Put i Vratnik u mrežu manjih lokalnih središta. Općina Karlobag prepoznaje Baške Oštarije (danas sa samo 30 stanovnika) kao jedino važnije stalno naselje na većim visinama velebitske primorske padine koje ima potencijal razvojnog središta.

Raskorak između planiranog i ostvarenog vidi se na primjeru naselja Jablanac koje je u Prostornom planu uređenja Grada Senja zbog niza potencijala (prednost položaja na ekvidistanci između Senja i Karlobaga, tranzitno trajektno čvorište i emitivna točka prema ulazu u NP Sjeverni Velebit, postojeća infrastruktura te prostorne rezerve za širenje) određeno kao lokalno središte, ali ne uspijeva realizirati atribute centra.

S druge strane, razvojni put naselja Starigrad Paklenica pokazuje koliko je važna mogućnost povezivanja središnjeg naselja i njegove okolice (plodno zaleđe Starigrada, aktivno uključivanje Nacionalnog parka Paklenica u turističku ponudu, dobra prometna povezanost), jači utjecaj i blizina većeg razvojnog žarišta (Zadar) te pitomiji reljef i klimatski uvjeti.

\section{Građevinska područja}

Građevinsko područje je područje određeno prostornim planom na kojemu je izgrađeno naselje i područje planirano za uređenje, razvoj i proširenje naselja, a sastoji se od građevinskog područja naselja, izdvojenog dijela građevinskog područja naselja i izdvojenog građevinskog područja izvan naselja.

Kriteriji za određivanje građevinskih područjanaselja ovise odemografskim procjenama, raspodjeli središnjih funkcija ili razvoja gospodarskih djelatnosti te prostornim ograničenjima koja proizlaze iz obilježja prostora i fizionomije naselja, a za područje Podgorja dodatno treba uzeti u obzir sustav zaštite i ograničenja koja proizlaze iz posebnih zakona.

Unutar prostora ograničenja građevinsko područje može se proširiti za najviše $20 \%$ površine njegova izgrađenog dijela, ako je taj izgrađeni dio veći od $80 \%$ površine toga građevinskog područja.

Novo izdvojeno građevinsko područje izvan naselja proizvodne namjene može se planirati samo izvan pojasa od $1000 \mathrm{~m}$ od obalne crte, osim za one djelatnosti koje po svojoj prirodi zahtijevaju smještaj na obali (brodogradilišta, luke i sl.).

Određeni su i uvjeti pod kojima se mogu planirati ugostiteljsko turističke i sportske namjene u prostorima ograničenja, pa se tako izdvojena građevinska 
Tablica 2. Udio neizgrađenog građevinskog područja (planirano za razvoj) u jedinicama lokalne samouprave

\begin{tabular}{|l|l|l|l|}
\hline & $\begin{array}{l}\text { GRAD } \\
\text { SENJ }\end{array}$ & $\begin{array}{l}\text { OPĆINA } \\
\text { KARLOBAG }\end{array}$ & $\begin{array}{l}\text { OPĆ INA } \\
\text { STARIGRAD }\end{array}$ \\
\hline $\begin{array}{l}\text { 1. GRAĐEVINSKA PODRUČJA NASELJA } \\
\text { (uključen izdvojeni dio GP područja naselja) }\end{array}$ & 698,1 ha & 322,4 ha & 476,4 ha \\
\hline 1.1. IZGRAĐENI DIO GP & 546,9 ha & 231,9 ha & 222,5 ha \\
\hline 1.2. NEIZGRAĐENI DIO GP & 151,2 ha & 90,5 ha & 253,9 ha \\
\hline $\begin{array}{l}\text { UDIO NEIZGRAĐENOG GP NASELJA } \\
\text { (planirano za razvoj) }\end{array}$ & $\mathbf{2 1 , 7 \%}$ & $\mathbf{2 8 , 1 \%}$ & $\mathbf{5 3 , 3 \%}$ \\
\hline $\begin{array}{l}\text { 2. GRAĐEVINSKA PODRUČJA IZVAN } \\
\text { NASELJA }\end{array}$ & 161,4 ha & nema podataka & 104,0 ha \\
\hline 2.1. POSLOVNA NAMJENA & 1,0 ha & 28,5 ha & 0,2 ha \\
\hline izgrađeno & 0,0 ha & nema podataka & 0,0 ha \\
\hline neizgrađeno (planirano za razvoj) & 1,0 ha & nema podataka & 0,2 ha \\
\hline 2.2. PROIZVODNA & 73,4 ha & 1,2 ha & 11,8 ha \\
\hline izgrađeno & 0,0 ha & nema podataka & 0,0 ha \\
\hline neizgrađeno (planirano za razvoj) & 73,4 ha & nema podataka & 11,8 ha \\
\hline 2.3. UGOSTITELJSKO-TURISTIČKA & 87,0 ha & 31,9 ha & 92,0 ha \\
\hline izgrađeno & 8,1 ha & nema podataka & 16,0 ha \\
\hline neizgrađeno (planirano za razvoj) & 78,9 ha & nema podataka & 76,0 ha \\
\hline $\begin{array}{l}\text { UDIO NEIZGRAĐENOG GP } \\
\text { IZVAN NASELJA (planirano za razvoj) }\end{array}$ & $\mathbf{9 5 , 0 \%}$ & nema podataka & $\mathbf{8 4 , 6 \%}$ \\
\hline
\end{tabular}

Izvor: Zavod za prostorno uređenje Ličko-senjska županije, Zavod za prostorno uređenje Zadarske županije, svibanj 2012. godine; Općina Karlobag, Izvješće o stanju u prostoru za razdoblje od 2010. do 2014. godine, veljača 2015. godine

područja izvan naselja ugostiteljsko-turističke i sportske namjene, u kojima se osnovna namjena (smještaj, sport) ostvaruje u izgrađenim strukturama, mogu se planirati na predjelima manje prirodne i krajobrazne vrijednosti.

Neizgrađeni dio građevinskog područja naselja, dio koji je planiran za daljnji razvoj, u Gradu Senju iznosi 21.7\%, u Općini Karlobag 28.1\% dok u Općini Starigrad čak 53.3\%. Znatnija je neizgrađenost građevinskih područja izvan naselja planiranih isključivo za poslovnu, proizvodnu i ugostiteljskoturističku namjenu, koje su osnova razvoja: u Općini Starigrad iznosi visokih 84.6\%, a u Gradu Senju čak 95.0\%.

$\mathrm{S}$ obzirom na mali udio izgrađenog dijela u ukupno planiranom građevinskom području u važećim prostornim planovima lokalne razine, 
proizlazi da su osigurane znatne površine za daljnji razvoj naselja. Posebno se to odnosi na planirana građevinska područja izvan naselja poslovne, proizvodne i ugostiteljsko-turističke namjena, koja su osnova za poticanje razvoja, a nisu još privedena planskoj namjeni.

Kroz izradu Prostornog plana Parka prirode Velebit otvara se mogućnost preispitivanja građevinskih područja naselja i izdvojenih dijelova građevinskog područja naselja.

\section{RAZVOJNI CILJEVI}

\section{Dokumenti u sustavu prostornog uređenja}

U Konačnom prijedlogu Strategije prostornog razvoja Republike Hrvatske određeni su prioriteti i usmjerenja prostornog razvoja među kojima se na prostor Podgorja posebno odnose: usmjerenje 1.4. Unapređenje vitalnosti i privlačnosti ruralnog prostora, 1.5. Održivi razvoj i korištenje obalnog područja, 1.6. Smanjivanje regionalnih razlika i održivo planiranje razvojno specifičnih područja (unutar prioriteta 1. Održivost prostorne organizacije) te usmjerenje 2.1. Održivo razvijanje zaštićenih područja prirode i ekološke mreže (unutar prioriteta Očuvanost identiteta područja) te usmjerenje 5.7. Razvijanje održivog turizma (unutar prioriteta 5. Otpornost na promjene).

U usmjerenju 1.6. Smanjivanje regionalnih razlika i održivo planiranje razvojno specifičnih područja, pod temom brdsko-planinskih područja ističe se da su očuvana cjelovitost i raznolikost krajobraza komparativne prednosti ovih područja koje treba pažljivo koristiti kao turistički potencijal. Održivo korištenje vrijednih neiskorištenih prirodnih resursa prema utvrđenim kriterijima zaštite okoliša temelj je njihova razvoja i ublažavanja razvojnog zaostajanja s obzirom na ostale dijelove Hrvatske.

U prostornim planovima razmatrane su mogućnosti i ograničenja prostornog razvoja i uređenja s obzirom na gospodarski i demografski razvoj, prostorno-krajobrazne i prirodne vrijednosti te kulturno-povijesne cjeline $\mathrm{i}$ građevine. Neki od zajedničkih ciljeva koji su prepoznati i određeni u prostornim planovima svih razina na području Podgorja jesu: održivo korištenje prirodne i kulturne baštine, razvoj turističkog potencijala (komplementarnost obalnog turizma sa sadržajima nacionalnih parkova i parka prirode), razvoj društvene infrastrukture, malog poduzetništva, tradicijskih djelatnosti, nautičkog turizma i marikulture, prometna povezanost sa zaleđem, oživljavanje povijesnih prometnica te izgradnja panoramskih cesta u turističke svrhe. 


\section{Razvojne strategije jedinica lokalne samouprave}

Ne postoji propisana metodologija ni smjernice za izradu razvojnih strategija jedinica lokalne samouprave pa se one izrađuju na različite načine. Analiza razvojnih ciljeva i mjera, koji su definirani razvojnim strategijama jedinica lokalne samouprave koje obuhvaćaju područje Podgorja, pokazuje da se zajednički ciljevi odnose na razvoj održivog, konkurentnog i diverzificiranog gospodarstva, prvenstveno turizma, te razvoj prometne, komunalne i društvene infrastrukture uz zaštitu prirodnih resursa.

\section{Cjelovito sagledavanje razvoja}

Unutar Okvira za provedbu u Konačnom prijedlogu Strategije prostornog razvoja Republike Hrvatske podržava se prostorno planiranje koje nadilazi administrativno-teritorijalne granice u rješavanju zajedničkih prostornorazvojnih i strateških pitanja zaštite okoliša i prirode. Ovo je posebno značajno za prostor Podgorja koji je prostorno-geografski jedna cjelina, a jedinice lokalne samouprave zbog demografske i gospodarske situacije te geografskog položaja pojedinačno imaju premale kapacitete za ostvarenje svojih razvojnih ciljeva.

Razvojne strategije jedinica lokalne samouprave ne razmatraju međusobno razvojno povezivanje, osim što trebaju biti usklađene s općim postavkama županijskih razvojnih strategija, pa se prilika za cjelovito sagledavanje prostora Podgorja i u razvojnom smislu pruža kroz izradu Prostornog plana Parka prirode Velebit.

Potencijal razvoja naselja u zaleđu je korištenje prirodnih vrijednosti Parka prirode Velebit, diversifikacija turističke ponude (npr. zdravstveni i ruralni turizam u višim podvelebitskim terasama), korištenje napuštenih gospodarstava u zaleđu za ekopoljoprivredu i plasiranje autohtonih proizvoda unutar Parka i na obali (za potrebe cjelogodišnjeg i ljetnog turizma). Otegotna okolnost su nesređeni imovinsko-pravni odnosi (većina objekata nije upisana u zemljišne knjige, veliki broj upisanih vlasnika i sl.) i katastar (stanje na terenu ne odgovara postojećim dostupnim kartama, usitnjenost čestica bez odgovarajućeg pristupa i dr.).

\section{ZAKLJUČAK}

\section{Razvojna ograničenja}

Razvojno problematični aspekti Podgorja jesu: reljef, klima, fizička izoliranost, nedostatna infrastruktura, izražena sezonalnost, depopulacija, velika raseljenost, rijetka mreža naselja, podiskorištenost resursa te sustavno zaostajanje u regionalnom razvoju. 
Nedostatna opremljenost primarnom infrastrukturom, uz raspršenost naselja i mali broj stanovnika, otežava uspostavljanje ekonomski održive mreže društvene infrastrukture. Nužno je stoga pronaći model za prilagođavanje prostornih standarda za osiguravanje dostupnosti društvene infrastrukture postojećoj situaciji i uvođenje novih tehnologija za pristup uslugama.

Sustav prostornog uređenja vezan je uz teritorijalni ustroj. Administrativne cjeline županija, gradova i općina često ne obuhvaćaju stvarna planska područja vezana uz pojedine razvojne aspekte i strateška pitanja okoliša. U tom smislu Prostorni plan Parka prirode Velebit može bolje sagledati razvojne izazove i potrebe Podgorja kao cjeline, uključivo preispitivanje rezerviranih prostora za razvoj.

\section{Razvojni izazovi}

Izazovi u promišljanju razvoja i aktivne zaštite prostora Parka prirode Velebit stoga jesu:

- rješavanje sukoba i usuglašavanje različitih interesa u procesu planiranja između pojedinih kategorija korisnika i sustava zaštite prostora, pri čemu se od svih dionika u ovom procesu očekuje visok stupanj suradnje $\mathrm{i}$ koordinacije na svim nivoima, uključivo aktivnu suradnju i usuglašavanje ciljeva lokalnih jedinica

- uspostavljanje jasnog određenja prema zatečenim prirodnim vrijednostima, krajobrazu i kulturnoj baštini prema očuvanju njihova izvornog oblika i razvijanje suvremenih oblika korištenja te iznalaženje modela kreativnog upravljanja tom, ali i cjelokupnom pokretnom i nepokretnom kulturnom baštinom

- obazriva revitalizacija ruralnih cjelina

- optimiziranje mreže naselja i osiguravanje dostupnosti društvene infrastrukture (odgoja i obrazovanja te zdravstvene zaštite) u uvjetima nedostatnog pristupa zaleđu i međusobne prometne povezanosti

\section{Razvojni potencijali}

Razvoj ovog područja treba temeljiti na komplementarnosti zaštite i razvoja kako bi se izbjeglo njihovo esencijalno sukobljavanje. Primarni razvojni potencijal je povezivanje turističke ponude obalnog dijela sa zaleđem kroz ekološki prihvatljiv turistički i posjetiteljski boravak u prostoru Parka prirode i prateći razvoj održivih gospodarskih djelatnosti kao što su: ekološka 
proizvodnja hrane s mogućim plasmanom na jadransko turističko tržište, malo poduzetništvo i obrti čija djelatnost ima uporište u tradiciji te seoski, sportsko-rekreacijski i lječilišni turizam. Pritom svakako treba izbjeći zamku prekomjerne komercijalizacije motivirane kratkoročnim tržišnim interesima, pogotovo nekritički obnovljenih tradicijskih građevina, i izvući pouke iz apartmanizacije obalnog područja. Jedan od preduvjeta za razvoj ovih djelatnosti je unaprjeđenje prometne povezanosti i dostupnosti atraktivnih prostora Parka prirode Velebit, ali i prostora iznimne ljepote u bližoj i široj okolici: nacionalnih parkova Sjeverni Velebit i Paklenica te Parka prirode Telašćica i nacionalnih parkova Kornati i Krka.

Premisa je stvaranje poželjnih uvjeta za život lokalnog stanovništva radi zaustavljanja procesa iseljavanja i privlačenja novih stanovnika. Pritom je nužno osvijestiti lokalnom stanovništvu prednosti boravka i života u zaštićenom području, čemu može pridonijeti i upoznavanje s pozitivnim razvojnim iskustvima u drugim zaštićenim područjima u Hrvatskoj te drugim državama, npr. zaštićenim planinskim područjima Slovenije i Austrije.

Dio Podgorja po svojim obilježjima pripada razvojno specifičnim područjima pa je u realizaciji razvojnih ciljeva moguće koristiti i instrumente politike regionalnog razvoja usmjerene na smanjenje regionalnih nejednakosti, npr. posebne intervencije iz državnog proračuna i namjenska sredstva iz fondova EU-a.

\section{Literatura}

Zakon o prostornom uređenju (Narodne novine, br. 153/13)

Zakon o zaštiti okoliša (Narodne novine, br. 80/13, 153/13 i 78/15)

Zakon o zaštiti prirode (Narodne novine, br. 153/13)

Strategija prostornog uređenja Republike Hrvatske (1997.)

Program prostornog uređenja Republike Hrvatske (1999.)

Konačni prijedlog Strategije prostornog razvoja Republike Hrvatske (2017.)

Prostorni plan uređenja Grada Senja (Službeni glasnik Grada Senja br. 11/06, 1/12, 6/14 i $10 / 14)$

Prostorni plan uređenja Općine Karlobag (Županijski glasnik Ličko-senjske županije br. $3 / 08$ i $12 / 10)$

Prostorni plan uređenja Općine Starigrad (Službeni Glasnik Zadarske županije br.16/06, $14 / 11$ i $20 / 16$ )

Prostorni plan Ličko-senjske županije (Županijski glasnik ličko-senjske županije br. 16/02, 17/02, 19/02, 24/02, 3/05, 3/06, 15/06, 19/07, 13/10, 22/10, 19/11, 4/15, $7 / 15$ i $6 / 16)$ 
Prostorni plan Zadarske županije (Službeni Glasnik Zadarske županije br. 2/01, 6/04, 2/05, 17/06, 25/09, 3/10, 15/14, 14/15 i 20/16)

Prostorni plan Nacionalnog parka Sjeverni Velebit (Narodne novine br. 35/12)

Prostorni plan Nacionalnog parka Paklenica (Narodne novine br. 23/01)

Općina Karlobag, Izvješće o stanju u prostoru za razdoblje od 2010. do 2014. godine, Karlobag, veljača 2015. godine

Razvojna strategija Grada Senja 2015. - 2020., Senj, 2015.

Strategija razvoja Općine Karlobag 2015. - 2020., Karlobag, 2016.

Strateški razvojni program Općine Starigrad za razdoblje 2015.-2020., Split 2016.

\section{THE ORIENTATION OF THE DEVELOPMENT OF PODGORJE THROUGH SPATIALLY-PLANNED DOCUMENTATION}

\section{Summary}

In the paper are an overview and analysis of the developmental perspectives of the orientation from the spatially-planned documentation for the realisation of the developmental possibilities of Podgorje with regard to the peculiarities of its geographical position, relief-climatic characteristics and historical heritage, and in particular the advantages and limitations for its development which result from the system of the protection of the whole region. The entire surface area of the subject region is located within a region of special interest for the state-protected coastal belt, inside the Velebit Nature Park and the ecological network of the Republic of Croatia, i.e. the EU Natura 2000 ecological network, and in the contact area of the Northern Velebit National Park and Paklenica National Park.

In the current system of spatial planning the propositions of the strategic documents of the spatial development and the spatially-planned documentation for the area of Podgorje on three levels are considered: the spatial plans of the state level for areas of special features, the county spatial plans and spatial plans of municipalities and towns, in the framework of the thesis that the role of spatial planning is the integration of different policies which influence a certain area, wherein the sustainability of development results from the synergistic development of economic, social, natural/environmental and cultural foundation of a space and society.

The system of spatial planning is primarily connected with the territorial makeup. By the law of territories of counties, towns and municipalities territorial units are defined which frequently do not include the actual planned area connected with the individual developmental aspects and strategic issues of the environment. In this sense the Spatial Plan of the Velebit Nature Park will be able to perceive the developmental challenges and needs of Podgorje as a whole.

Keywords: Podgorje, spatial planning, protected areas, spatial plan, Velebit Nature Park, developmental goals, developmental potentials, developmental limitations 